\title{
Effects of Chia Flour Incorporation on the Nutritive Quality and Consumer Acceptance of Chips
}

\author{
Ranil Coorey ${ }^{1}$, Alexandra Grant ${ }^{1} \&$ Vijay Jayasena ${ }^{1}$ \\ ${ }^{1}$ School of Public Health, Curtin Health Innovation Research Institute, Curtin University, Perth, Western \\ Australia 6845, Australia \\ Correspondence: Ranil Coorey, Ranil Coorey School of Public Health, Curtin University, GPO Box U1987, Perth, \\ Western Australia 6845, Australia. Tel: 61-8-92-661-043. E-mail: r.coorey@curtin.edu.au
}

\author{
Received: September 7, 2012 Accepted: September 20, 2012 Online Published: October 25, 2012 \\ doi:10.5539/jfr.v1n4p85 \\ URL: http://dx.doi.org/10.5539/jfr.v1n4p85
}

\begin{abstract}
Gluten free, antioxidant, calcium and dietary fibre rich, chia is known to contain the highest level of omega-3 available in any cultivated plant source. The objective of this research was to develop a high protein, high dietary fibre, gluten free and omega-3 fatty acid rich chips. Four different levels of whole chia flour $(5 \%, 10 \%, 12 \%$, and $15 \%$ ) were incorporated to produce chia chip. There were no significant differences in appearance, colour, flavour and overall liking between a commercial chip sample and the $5 \%$ chia chips. The chemical analysis indicated that all four trial chips are excellent sources of omega- 3 and the baking process has a limited impact on their nutritional profile. For optimal consumer acceptance and nutritional benefits, the incorporation of $5 \%$ chia is recommended. With limited chia based food products currently available, a chia chip would be a well-accepted and healthy alternative to the common unhealthy chips.
\end{abstract}

Keywords: chia, chia seeds, chia flour, healthier chips, chia chips, omega-3, snack food

\section{Introduction}

Salvia hispanica $L$. or chia is an annual plant belonging to the Lamiaceae family native to Mexico and Guatemala (Ixtaina et al., 2008). The name Salvia originates from the Latin word Salvare, meaning 'the healer' (Goren et al., 2006). The seeds of the species Salvia hispanica L., more commonly referred to as 'chia', were once cultivated by Aztec and Mayan tribes for use as a food source and production of medicines and paints (Ayerza \& Coates, 2005; Ixtaina et al., 2008). Chia is grown commercially for its black and white seeds which are naturally rich in omega-3 fatty acids (FA), antioxidants, dietary fibre, protein, calcium and various other essential nutrients (Ixtaina et al., 2008). These factors have initiated a growth in the popularity of the chia seed in recent years.

Omega-3 and omega-6 FAs are essential polyunsaturated fatty acids (PUFAs). Alpha linolenic acid (ALA) and linoleic acid (LA) are the major long chain FAs belonging to the omega-3 and omega- 6 groups respectively. LA and ALA are required for structural integrity of cell membranes as well as being precursors for longer chain FAs which are required for eicosanoid compounds, prostaglandins and leukotrienes (Mann \& Truswell, 2007). LA is converted to arachidonic acid in the body, while ALA is metabolized to yield the long chain FA eicosapentaenoic acid (EPA), which further undergoes elongation, desaturation and alpha oxidation to produce docosahexaenoic acid (DHA) (Adkins \& Kelley, 2010). Metabolism of dietary LA to arachidonic acid uses the same enzymes ( $\Delta 6$ desaturase elongase $\Delta 5$ desaturase) as in the synthesis of DHA from ALA. As this pathway is shared by the two FAs, they compete for the same enzymes, which means a high ratio of LA to ALA in the diet reduces the amount of ALA converted to EPA and DHA (Adkins \& Kelley, 2010; Mann \& Truswell, 2007). Thereby reducing the possible chances to convert ALA to EPA and DHA, which are the compounds beneficial to humans, hence, a diet of high ALA is beneficial.

Adkins and Kelley (2010) review found that numerous epidemiological studies have demonstrated the benefits of dietary omega-3 PUFAs on cardiovascular health. Intervention studies have established that omega- 3 is beneficial for both primary and secondary prevention of cardiovascular disease. The decline of omega-3 FA in western diets over the last century, due to increased consumption of processed foods high in total dietary lipids and saturated FA, has been associated with the increased prevalence of cardiovascular diseases (Okuyama, 2001). Animals fed diets high in omega-6 FA produce meat and milk which are also high in omega-6 FA (Okuyama, 2001), which demonstrates the need to produce food products with an improved lipid profile (Coates \& Ayerza, 1998). 
Omega-3 FA are present in marine animals, oil seeds, some leafy vegetables and macro and micro algae. Fish and oil seeds are the most common and important sources of omega-3 in the human diet (Mishra et al., 1993). Usually fish oil presents higher levels of omega-3 than oil seeds (Bozan \& Temelli, 2008; Rubio-Rodriguez et al., 2010; Dubois et al., 2007; Mann \& Truswell, 2007). Chia oil, however, has a higher percent of omega-3 per $100 \mathrm{~g}$ than cod liver, herring, salmon and sardine oils (Rubio-Rodriguez et al., 2010). With the decline in global fish stocks and contamination of fish species with heavy metals and organic pollutants future supply of fish oil will be limited. For this reason the benefits of fish as a regular source of omega-3 are often questioned and alternate plant sources need to be investigated (Rubio-Rodriguez et al., 2010). Chia is an excellent alternative as it is the richest known botanical source of alpha linolenic acid. It is also a low cost alternative to fish and suitable for vegetarians (Ayerza \& Coates, 2005). Furthermore, chia is a good source of omega-3 for commercial food applications because it can be added straight to products without flavour alterations, commonly required in products containing added fish oil. Other oil seeds such as flax, with high concentrations of ALA, contain anti-nutritional and vitamin antagonistic factors. Chia seeds are not reported to have these anti-nutritional factors (Ayerza \& Coates, 2005).

The present study investigated the effects of adding omega-3 rich chia in to a chip and processed it to determine the effects on the chips nutritional composition and sensory attributes. There is also a niche market for gluten free products. The demand for gluten free foods are expected to grow rapidly due to the increased prevalence of gluten intolerance (Han et al., 2010; Cummins \& Roberts-Thomson, 2009). There are only a few omega- 3 enriched snack foods with good sensory acceptability currently available in the market that are also suitable for those that are gluten intolerant. The main objective of this research was to create a chip-like snack that was high in protein and omega-3 in a $50 \mathrm{~g}$ serve, which was also gluten free containing chia as definded by the Australian New Zealand Food Authority (1995) proposed nutrient claims.

\section{Materials and Methods}

\subsection{Chip Production}

A rice and potato based chip-like snack food product was produced containing 5 different levels of commercial chia flour $(0 \%$ as the control, $5 \%, 10 \%, 12 \%$ and $15 \%)$. Gluten free ingredients, rice and potato flours (in the ratio 1.2:1), salt, vegetable oil, flavouring, (table 1) were used. The control ( $0 \%$ chia flour) formulation was selected based on a preliminary pilot study, the commercial chia flour was obtained from The Chia Company, Melbourne, Victoria, Australia and all other ingredients were sourced from Coles and Woolworths supermarkets within the Perth metropolitan area.

Table 1. Formulation of control and trial chips

\begin{tabular}{lccccc}
\hline \multirow{1}{*}{ Ingredient } & Control (\%) & \multicolumn{4}{c}{ Treatments (\%) } \\
\cline { 3 - 6 } & & $\mathbf{1}$ & $\mathbf{2}$ & $\mathbf{3}$ & $\mathbf{4}$ \\
\hline Chia flour & 0.0 & 5.0 & 10.0 & 12.0 & 15.0 \\
Rice flour & 31.0 & 28.5 & 26.0 & 25.0 & 23.5 \\
Potato flour & 27.0 & 24.5 & 22.0 & 21.0 & 19.5 \\
Salt & 2.0 & 2.0 & 2.0 & 2.0 & 2.0 \\
Vegetable Oil & 2.0 & 2.0 & 2.0 & 2.0 & 2.0 \\
Flavouring & 3.0 & 3.0 & 3.0 & 3.0 & 3.0 \\
Water & 35.0 & 35.0 & 35.0 & 35.0 & 35.0 \\
\hline
\end{tabular}

Rice flour and warm water at $40^{\circ} \mathrm{C}$ were first mixed by a hand-held mixer (Sunbeam Model number V175721, Japan) at speed setting 5 for 4 minutes. The salt and flavouring were added and mixed in the same hand-held mixer at speed setting 5 for 5 minutes. The potato flour and chia flour were mixed together separately in the same Sunbeam mixer at speed setting 5 for 5 minutes before being added to the rest of the ingredients and mixed thoroughly into a workable dough in a Hobart mixer (model N50G, Ohio, USA) set at speed 3 for 5 minutes. The dough was allowed to rest for one hour covered by a moist cloth to prevent it drying out.

A La Monferrina pasta machine (Model P1, Vespussi, Italy) was used to roll the dough in stages to a thickness of $10 \mathrm{~mm}$, then $5 \mathrm{~mm}$, then $3 \mathrm{~mm}$ and finally $1 \mathrm{~mm}$. In between each feed through the rollers, the dough was dusted lightly with rice flour and folded in half. A circular cookie cutter of $5 \mathrm{~cm}$ diameter was used to create the chip 
shapes in the rolled dough. To ensure uniform appearance a canola oil spray was used to lightly coat the chips before being baked in a fan forced Franke oven (Model 24, Aaburg, Switzerland) at $180^{\circ} \mathrm{C}$ for 12 minutes.

The five chip samples and the chia flour were frozen at $-80^{\circ} \mathrm{C}$ after production for two weeks in resealable freezer bags only for chemical testing and it was not expected that the freeze thaw process will have an impact on the chemical composition. For the sensory testing fresh batches of the chips were made just prior to the evaluation.

\subsection{Chemical Analysis}

The samples were prepared in triplicate for analysis. For each analysis, five chips were randomly selected from each sample, ground and thoroughly mixed to ensure homogeneity and to make certain the sample was an accurate representation of the total.

\subsection{Moisture Content}

Moisture content was determined according to the AOAC official method 945.15 (2005) for cereal adjuncts. Approximately $10 \mathrm{~g}$ of each sample was accurately weighed into pre-dried and cooled aluminium dishes and dried in a $105^{\circ} \mathrm{C}$ air oven until constant weight. Samples were cooled in a desiccator before reweighing and moisture content was calculated by difference.

\subsection{Crude Protein}

Crude protein was measured using the Kjeldahl method according to the AOAC official method 945.18 (2005) for cereal adjuncts. Approximately $1 \mathrm{~g}$ of the ground sample was accurately weighed into digestion tubes containing a Kjetab catalyst and glass bead to which the digestion acid and hydrogen peroxide were added. One gram of sucrose was used as a blank. The percent protein in the samples was calculated using the following equation:

$$
\text { Protein }(\%)=\frac{(m l \text { sample }- \text { ml blank titre })}{m g \text { sample }} \times 0.1 M H C L \times 14.1 \times f \times 100
$$

The conversion factor (f) of 5.70, was used to calculate the protein content (Mosse, 1990).

\section{$2.5 \mathrm{Ash}$}

Ash content was determined as per the AOAC official method 927.02 (2005). Approximately $5 \mathrm{~g}$ of sample was weighed exactly into pre-dried and cooled crucibles. Samples were heated on a hot plate until smoking ceased and then placed in a muffle furnace (Thermolyne model 4800 , USA) at $550^{\circ} \mathrm{C}$ overnight. Percent ash was calculated by the difference.

\subsection{Dietary Fibre}

Dietary fibre was determined according to the AOAC official method 991.43 (2005), which is the MES-TRIS buffer method. Approximately $1 \mathrm{~g}$ sample $(\mathrm{m})$ was incubated with alpha amylase, protease and amyloglucosidase to solubilise, hydrolyse and depolymerise the starch and proteins. Samples were then treated with ethanol to precipitate the soluble fibre. The residue (R) was filtered, washed with ethanol and acetone, dried and weighed. Percent total dietary fibre was calculated as the weight of the filtered and dried residue, minus the protein and ash, using the following equation. Protein and ash contents were determined as per above.

$$
\text { Dietary fibre }(\%)=\frac{\left[\frac{R 1+R 2}{2}\right]-(P+A+B)}{\left[\frac{m 1+m 2}{2}\right]} \times 100
$$

Where:

$\mathrm{m} 1=$ sample weight $1 ; \mathrm{m} 2=$ sample weight 2 ; per sample per test;

$\mathrm{R} 1$ = residue weight 1 from $\mathrm{m} 1 ; \mathrm{R} 2$ = residue weight 2 from $\mathrm{m} 2$;

$\mathrm{A}=$ ash weight from $\mathrm{R} 1 ; \mathrm{P}=$ protein weight from $\mathrm{R} 2$; and

$$
B=B l a n k=\left(\frac{B R 1+B R 2}{2}\right)-(B P+B A)
$$

Where:

$\mathrm{BR}=$ blank residue; 
$\mathrm{BP}=$ blank protein from $\mathrm{BR} 1$

$\mathrm{BA}=$ blank ash from $\mathrm{BR} 2$

2.7 Calcium

Calcium content was determined by ashing and acid extraction as per the AOAC official method 927.02 (2005) and analysed by atomic absorption spectrophotometer (GBC Avanta E, Australia). Due to the expected high concentration of calcium in the samples they were diluted by 1:10 ratio. Ten millilitres of lanthanum (i.e. 100,000 $\mathrm{ppm}$ ) was added to each flask and made up to volume with deionised (DI) water. Four standards, $5 \mathrm{ppm}, 10 \mathrm{ppm}$, $20 \mathrm{ppm}$ and $50 \mathrm{ppm}$ of calcium in deionised water along with a blank; lanthanum at 100,00 ppm in DI water were used in developing the calibration curves.

\subsection{Antioxidant Activity}

To evaluate the antioxidant activity of samples methanol extracts were allowed to react with stable radical, 2,2-diphenyl-1-picrylhydrazyl (DPPH) according to the methods of as modified by Esposito et al. (2005) and Ramadan and Moersel (2006). The reduction of DPPH causes a bleaching of the purple coloured solution and a decrease in absorbance at a specific wavelength during the reaction (Tepe et al., 2006). In its free radical form DPPH has a peak absorbance at $515 \mathrm{~nm}$, upon reduction however the absorption disappears (Brand-Williams et al., 1995; Sanchez-Moreno et al., 1998).

One gram of sample was suspended in $10 \mathrm{ml}$ (for chips) or $20 \mathrm{ml}$ (for chia flour) $1 \%$ methanol in water and mixed in a shaking water bath for 45 minutes. The different dilution factors were used for the chia flour and chips due to the expected higher concentration of omega- 3 in the chia flour. Samples were centrifuged at $4000 \mathrm{~g}$ for 10 minutes (Esposito et al., 2005). One hundred micro litres or two hundred micro litres of supernatant was added to $3.9 \mathrm{~mL}$ of DPPH $0.025 \mathrm{~g} / \mathrm{L}$ methanol for the chip and chia flour samples respectively (Brand-Williams et al., 1995; Sanchez-Moreno et al., 1998). The solutions were vortexed for ten seconds, corked (to stop evaporation) and incubated at room temperature in a dark room for 60 minutes (Ramadan and Moersel, 2006).

Against a control of $1 \%$ methanol in water, the decrease in absorbance at $515 \mathrm{~nm}$ was measured using a Novaspec II visible recording spectrophotometer (Pharmacia Biotech, Cambridge, England) as per Ramadan and Moersel (2006). Percent antioxidant activity was calculated from the following equation:

$$
\text { Antioxidant activity }(\%)=\left(\frac{\text { Abs.of control }- \text { Abs.of sample }}{\text { Abs.of control }}\right) \times 100
$$

(Ramadan \& Moersel, 2006)

\subsection{Crude Fat}

The method for total lipid determination followed the AOAC official method 945.18 (2005) for cereal adjuncts. The fat content was determined using $5 \mathrm{~g}$ sample via petroleum ether extraction using a BUCHI Soxlet fat extraction unit (Buchi model E-816, Switzerland) over a two hour period. Crude fat was calculated as per the following equation:

$$
\text { Crude fat }(\%)=\left[\frac{(\text { Weight of extraction cup containing fat }- \text { Weight of empty extraction cup })}{(\text { Weight of thimble and dample }- \text { weight of thimble })}\right] \times 100
$$

\subsection{Fatty Acid Composition}

The method followed was the AOAC official method 983.23 (2005) as modified by Phillips et al. (1997) where a chloroform-methanol cold extraction technique was used to obtain the oil. Five grams of sample was weighed out into $500 \mathrm{ml}$ centrifuge tubes and $32 \mathrm{ml}$ of $0.5 \mathrm{M}$ sodium acetate solution, $80 \mathrm{ml}$ of methanol and $40 \mathrm{ml}$ of chloroform were added. The resulting proportion of chloroform: methanol: water was 1:2:0.8 (vol $/ \mathrm{vol} / \mathrm{vol})$. Centrifuge bottles were capped and shaken in a Ratek shaking water bath at room temperature for 30 minutes. For each sample, $40 \mathrm{ml}$ of chloroform was added and the samples were shaken for a further 30 minutes, followed by the addition of $40 \mathrm{ml}$ of DI water and shaken for 30 minutes. The resultant ratio of chloroform: methanol: water was 2:2:1.8 ( $\mathrm{vol} / \mathrm{vol} / \mathrm{vol})$. The capped bottles were centrifuged at $2300 \mathrm{rpm}$ at room temperature for ten minutes to clarify the organic, inorganic and solids (sample) layers. The bottom organic layer was syphoned from the centrifuge tubes, transferred to a beaker and left overnight to allow chloroform to evaporate (Phillips et al., 1997).

Analysis of the FA in food is typically performed as methyl esters. This is due to free fatty acids (FFA) and triacylglycerides being difficult to analyse by gas chromatography as a result of their poor peak shape and quantification. Oil samples from the chloroform-methanol extraction were derivatised using $\mathrm{BCl}_{3}-\mathrm{Methanol}_{1} \%$ 
w/w, according to the Sigma-Aldrich (1997) procedure. Fifty milligrams of sample was added to $10 \mathrm{ml}$ screw top test tubes and dissolved in $2 \mathrm{ml}$ of the non polar organic solvent toluene. To this $2 \mathrm{ml} \mathrm{BCl}_{3}$-Methanol was added which was flushed with $\mathrm{N}_{2}$ gas and heated to $60^{\circ} \mathrm{C}$ for ten minutes in a water bath. Two millilitres of water and $2 \mathrm{ml}$ of hexane were then added to the cooled reaction vessels. Samples were shaken lightly to ensure all the esters were dissolved in the nonpolar solvent and the upper, organic, layer was carefully removed. Another $2 \mathrm{ml}$ of both water and hexane were added back to the samples and the organic layer was extracted a second time to ensure no oil was remaining. Anhydrous sodium sulphate was used to dry the samples. Finally, samples were transferred to $10 \mathrm{ml}$ volumetric flasks and filled to volume with hexane.

The FA, as their methyl esters, were analysed via gas chromatography, using a Perkin Elmer (USA) model AutosystemXL, equipped with a SGE forte BPX 70 capillary column $30 \mathrm{~m}$ x $0.32 \mathrm{~mm}$ x $0.25 \mu \mathrm{m}$ (SGE Analytical Science Pty. Ltd., Ringwood Victoria Australia). The injector and FID detector ports were set at $200^{\circ} \mathrm{C}$ and $250^{\circ} \mathrm{C}$ respectively. The oven temperature was initially set at $80^{\circ} \mathrm{C}$ for the first 2 minutes, and then increased at a rate of $45^{\circ} \mathrm{C} /$ minute to $130^{\circ} \mathrm{C}$, where it remained for 10 minutes. It was then increased at a rate of $2^{\circ} \mathrm{C} /$ minute to $172^{\circ} \mathrm{C}$, where it remained for the final 6 minutes. The carrier gas was helium at $20 \mathrm{~mL}$ per minute. One $\mu \mathrm{L}$ of each sample was injected using an auto sampler and each peak was identified using a Sigma-Aldrich pure methyl ester standard. Quantification of FA was calculated using the following equation:

$$
\text { Fatty acid }(\%)=\left(\frac{\text { FAconcentration } \times \text { dilution factor } \times \text { extractant volume }}{\text { Sample weight }}\right) \times 100
$$

\subsection{Sensory Analysis}

\subsubsection{Recruitment of Panellists}

A total of 72 subjects over the age of 18 participated in the study. However 9 evaluation forms were disregarded due to incorrect completion or incompletion, leaving a total of 63. The number was above that for the minimum number of assessors, 49, required for a two sided test as stipulated in the Australian Standard AS 2542.2.1-2007. As suggested by the Australian Standard AS 2542.1.1-1995 'General guidelines to methodology - Selection of assessors' smokers, individuals who are generally not in good health and those with known food allergies were not included in the trial. General demographic data (age, gender, nationality, suburb, health and snack food consumption habits) were collected.

\subsubsection{Sensory Methods}

The sensory evaluation was conducted as per the processes described by the Standards Association of Australia AS 2542.1.3-1995 and AS 2542.1.1-2005 for sensory analysis. The labs were equipped with 6 individual assessment booths for private assessment and a sensory information management system. A 9-point hedonic rating scale (1=dislike extremely; $5=$ neither like nor dislike; $9=$ like extremely) was used to assess each panellist's preference for appearance, colour, smell, texture, flavour and overall liking, as per the Standards Association of Australia AS 2542.2.3-2007 and AS 2542.1.1-2005. Three digit codes were randomly assigned to the 5 samples across the six sensory booths. The methods and order of presentation as recommended by Ruskey and Savage (1993) were followed. A total of 63 subjects, consisting of 18 male and 45 female, over the age of 18 participated in the sensory analysis.

\subsection{Data Analysis}

The data from the chemical composition analysis of the samples and for the sensory analysis was analysed for statistical significance $(\mathrm{P}<0.05)$ via analysis of variance (ANOVA). Results obtained from the screening questionnaire as part of the sensory analysis were pooled and descriptive statistics were generated. The sensory data was analysised for statistical significance via Kruskal-Wallis. All data analyses were conducted using the Statistical Package for Social Sciences version 19.0 (SPSS 19.0) running on a personal computer.

\section{Results and Discussion}

\section{1 Chip Production}

It has been reported that the combination of rice and potato flour is ideal for the production of chips due to the developed distinct flavour and texture (Luh, 1991; Hui, 2006). Rice flour is also known to improve texture in similar chip like products (Quintero-Fuentes et al., 1999; Hui, 2006).

According to the experimental design chia flour was to be added at levels of $0 \%, 5 \%, 10 \%, 15 \%$ and $20 \%$. However, at $15 \%$ inclusion, the dough was very sticky and unable to be rolled thin enough for chip manufacturing. The reason for such stickiness could be the high water absorption and good gelling properties of the chia. From a 
production stance $15 \%$ is the highest level of chia that can be used to manufacture chips with the current formulation. Hence a $20 \%$ chip was not attempted and levels of $0 \%, 5 \%, 10 \%, 12 \%$ and $15 \%$ chia were used as treatments.

The control ( $0 \%$ chia) sample, did not hold together well enough to be put through the pasta machine. During the preliminary pilot study it was observed that when water was added to the chia flour it forms a gel that acts as a binding agent similar to gluten does in wheat based products. However, in the control sample without the chia, there was no gel present to act as a binding agent. Instead the chips were hand rolled to a thickness of $3 \mathrm{~mm}$, which was as thin as they could be produced without breakage. As a result the control sample was therefore used for analytical purposes only. A commercially available, Sultry Sally (Sydney, Australia) brand original flavour baked chips were used as the control for sensory analysis. The product was purchased at retail in the Perth, Western Australia metropolitan area and the longest possible shelf-life products were chosen to ensure freshness. The commercial sample contained potato, maize, polenta, sunflower oil, sea salt, emulsifier 471 and flavour. The product was considered similar to the test samples, i.e. gluten free, lower fat, healthier chips. The commercial product was selected due to its similarity to the test samples in appearance, flavour and texture.

\subsection{Chemical Analysis}

The mean moisture content for chia flour was $5.30 \%$ which is within the range of 4.3 to $7.2 \%$ reported by numerous authors (Ixtaina et al., 2008; Bushway et al., 1981; Olivos-Lugo et al., 2010). The mean proximate analysis values on dry basis for the chia flour, control and trial chip samples are listed in Table 2.

Table 2. Proximate analysis and anti-oxidative activity of samples (on dry basis)

\begin{tabular}{|c|c|c|c|c|c|c|c|}
\hline Sample & & $\begin{array}{l}\text { Protein } \\
(\mathrm{g} / 100 \mathrm{~g})\end{array}$ & $\begin{array}{c}\text { Fat } \\
(\mathrm{g} / 100 \mathrm{~g})\end{array}$ & $\begin{array}{c}\text { Dietary fibre } \\
(\mathrm{g} / 100 \mathrm{~g})\end{array}$ & $\begin{array}{c}\text { Ash } \\
(\mathrm{g} / 100 \mathrm{~g})\end{array}$ & $\begin{array}{l}\text { Calcium } \\
(\mathrm{mg} / 100 \mathrm{~g})\end{array}$ & $\begin{array}{l}\% \text { anti-oxidative } \\
\text { activity }\end{array}$ \\
\hline Chia flour & & 19.74 & 37.77 & 43.09 & 4.97 & 951.20 & 92.84 \\
\hline Control & (0\% chia) & $3.87^{\mathrm{a}}$ & $3.88^{\mathrm{a}}$ & $2.79^{a}$ & $5.89^{a}$ & $0.00^{\mathrm{a}}$ & $1.32^{\mathrm{a}}$ \\
\hline Treatment 1 & (5\% chia) & $5.10^{b}$ & $4.46^{\mathrm{a}}$ & $2.91^{\mathrm{a}}$ & $6.29^{\mathrm{ab}}$ & $39.75^{b}$ & $5.55^{\mathrm{b}}$ \\
\hline Treatment 2 & $(10 \%$ chia $)$ & $5.97^{c}$ & $5.30^{\mathrm{a}}$ & $8.20^{b}$ & $7.11^{b}$ & $94.85^{c}$ & $25.66^{\mathrm{c}}$ \\
\hline Treatment 3 & (12\% chia) & $6.59^{\mathrm{cd}}$ & $3.78^{\mathrm{a}}$ & $10.43^{\mathrm{c}}$ & $6.54^{b}$ & $110.41^{\mathrm{d}}$ & $35.01^{\mathrm{d}}$ \\
\hline Treatment 4 & (15\% chia) & $7.14^{d}$ & $3.32^{\mathrm{a}}$ & $11.72^{\mathrm{c}}$ & $7.33^{b}$ & $126.21^{\mathrm{e}}$ & $44.04^{e}$ \\
\hline
\end{tabular}

Different superscripts within different columns for trial samples denote significant differences $(\mathrm{P}<0.05)$.

The protein content of the chia flour was $19.74 \mathrm{~g} / 100 \mathrm{~g}$ which is in the range of $19-24 \mathrm{~g} / 100 \mathrm{~g}$ reported by Ixtaina et al (2008). The protein content of the chips followed a clear linear trend with the control $(0 \%$ chia $)$ chip sample having the lowest percentage protein and the $15 \%$ containing sample having the highest level. The four trial chips all had a significantly higher level of protein than the control chip. The protein level in the $10 \%$ chip was significantly higher than that in the 5\% chip, however the differences in protein contents between $10 \%$ and $12 \%$, and between $12 \%$ and $15 \%$ were not statistically significant even though they showed an increasing trend. The increase in protein content in the sample chips is due to the added chia as the $0 \%$ chia control sample contained the lowest protein content, which indicates that chia can significantly increase protein content in a chip like product.

The fat content of chia flour was found to be $37.77 \mathrm{~g} / 100 \mathrm{~g}$ which is at the upper end of the range $32-37 \mathrm{~g} / 100 \mathrm{~g}$ reported by Bushway et al. (1981) and Coates and Ayerza (1998), which may be affected by growing conditions. It would be expected that as the level of chia increased, the level of fat would increase proportionally in the chips. However there was no significant $(\mathrm{P}>0.05)$ difference in fat content between all five chip samples. It is possible that the strong water and oil binding properties of chia would have interfered with the Soxlet fat extraction process, resulting in the incomplete extraction of the oil, which may account for these unexpected values (unpublished data).

The dietary fibre (DF) content of the chia flour was found to be $43.09 \mathrm{~g} / 100 \mathrm{~g}$ which is higher than the range (35 $40 \mathrm{~g} / 100 \mathrm{~g}$ ) reported by Reyes-Caudillo et al. (2008). This variation could be due to difference in growing conditions. As expected the control chip sample had the lowest DF content, with an increasing trend with the 5\%, 
$10 \%, 12 \%$ and $15 \%$, addition of chia. As the guidleins of the Australian New Zealand Food Authority (1995) proposed nutrient claims in food labeling and advertising, a $50 \mathrm{~g}$ serve of the $10 \%, 12 \%$ and $15 \%$ added chia chips could be classified as being "high in fibre".

The ash content of the chia flour was $4.97 \mathrm{~g} / 100 \mathrm{~g}$ which is within the literature value range $4.61-5.96 \%$ (Olivos-Lugo et al., 2010; Bushway et al., 1981; The Chia Company, 2010). The ash content of the chips increased with increasing level of added chia. The ash content of the $10 \%, 12 \%$ and $15 \%$ chips was significantly higher than the control sample, once again indicating that the addition of chia at levels greater than $5 \%$ in a chip like product will increase the mineral content.

The calcium content of the chia flour was $951.20 \mathrm{mg} / 100 \mathrm{~g}$ which is higher than the literature states; $500-540$ $\mathrm{mg} / 100 \mathrm{~g}$ (Bushway et al., 1981; The Chia Company, 2010). Such high level of calcium may be explained by variations due to growing conditions and location. In the trial samples calcium content increased with increasing level of added chia. Calcium was not detected in the control chip sample. The levels of calcium in all the trial chip samples were significantly higher than the control $(\mathrm{p}<0.05)$.

The antioxidant activity of the chia flour, control and chip samples is listed in table 2. Percentage anti-oxidative activity of free radical scavenging system was $92.84 \%$ for the chia flour. This value is significantly higher than the range of 20.7 to $49.7 \%$ found in other similar plants species by Tepe et al. (2006). Hence it can be seen that the chia, compared with other similar plant sources, exhibits excellent antioxidant activity. The antioxidant activity of the chips increased significantly with the increasing percentage of chia inclusion.

The characterisation of the lipid fraction of the chia flour, control and the treatments is summarised in Table 3. Palmitic, stearic, eicosonoic (all of which are saturated FA), oleic (mono unsaturated FA), LA and ALA (are poly unsaturated FA) were specifically measured as they had previously been investigated. Palmitic acid went undetected in the chia flour and all chips. Stearic acid was found to be $3.56 \%$ in the chia flour's fat content, which is close to that of the literature range 2.8 - 3.2\% (Ayerza, 1995; Heuer et al., 2002; Dubois et al., 2007; Coates \& Ayerza, 1998; Alvarez-Chavez et al., 2008). Eicosanoic acid was found at very low levels in the chia flour, control and trial chips. The reported levels eicosanoic acid has been within the range of $1.0-1.1 \%$ of the raw chia fat (Alvarez-Chavez et al., 2008; Dubois et al., 2007). The lower amount of eicosanoic acid in the present study could be due that particular FA being lost in the grinding process in flour manufacture. The addition of chia in to the chip had no significant effect on the eicosanoic acid concentration.

The oleic acid content in the chia flour was $7.19 \%$, which is within the range; $(6.2-8.2 \%)$ reported by Ayerza (1995); Heuer et al. (2002); Dubois et al. (2007); Coates and Ayerza (1998); and Alvarez-Chavez et al. (2008). With increasing percentage of added chia the proportion of oleic acid in the chips decreased. This suggests that oleic acid was majorly present in the commercially available vegetable oil used in the chip manufacture, rather than in the chia oil.

Table 3. Fatty acid profile (g of fatty acid / $100 \mathrm{~g}$ of oil)

\begin{tabular}{llcccccc}
\hline Sample & & Palmitic & Stearic & Eicosanoic & Oleic & LA & ALA \\
\hline Chia flour & & ND $^{*}$ & 3.56 & 0.42 & 7.19 & 20.45 & 53.4 \\
Control & $(0 \%$ chia $)$ & ND & $1.64^{\mathrm{a}}$ & $0.42^{\mathrm{a}}$ & $30.17^{\mathrm{a}}$ & $13.97^{\mathrm{a}}$ & $5.39^{\mathrm{a}}$ \\
Treatment 1 & $(5 \%$ chia $)$ & $\mathrm{ND}$ & $2.08^{\mathrm{b}}$ & $0.26^{\mathrm{a}}$ & $27.57^{\mathrm{a}}$ & $15.87^{\mathrm{ab}}$ & $15.09^{\mathrm{b}}$ \\
Treatment 2 & $(10 \%$ chia $)$ & $\mathrm{ND}$ & $2.48^{\mathrm{b}}$ & $0.36^{\mathrm{a}}$ & $23.42^{\mathrm{b}}$ & $15.93^{\mathrm{ab}}$ & $19.15^{\mathrm{c}}$ \\
Treatment 3 & $(12 \%$ chia $)$ & $\mathrm{ND}$ & $2.09^{\mathrm{b}}$ & $0.34^{\mathrm{a}}$ & $19.01^{\mathrm{c}}$ & $15.13^{\mathrm{ab}}$ & $20.94^{\mathrm{d}}$ \\
Treatment 4 & $(15 \%$ chia $)$ & $\mathrm{ND}$ & $2.76^{\mathrm{b}}$ & $0.35^{\mathrm{a}}$ & $18.23^{\mathrm{c}}$ & $19.38^{\mathrm{b}}$ & $30.01^{\mathrm{e}}$ \\
\hline
\end{tabular}

Different superscripts within different columns for trial samples denote significant differences $(\mathrm{P}<0.05)$;

${ }^{*} \mathrm{ND}=$ not detected.

LA or omega-6 FA was $20.45 \%$ in the chia flour oil, which is close to the literature range of $17.6-20.4 \%$ (Ayerza, 1995; Heuer et al., 2002; Dubois et al., 2007; Coates \& Ayerza, 1998; Alvarez-Chavez et al., 2008). Only the 15\% chia included chip showed a significantly higher LA concentration compared to the control. 
The level of ALA or omega- 3 FA found in the chia flour oil was $53.4 \%$ which is outside the range of that recorded in the literature; 61.3 - 65.1\% (Ayerza, 1995; Heuer et al., 2002; Dubois et al., 2007; Coates \& Ayerza, 1998; Alvarez-Chavez et al., 2008). This variation may be the result of seasonal differences, batch differences and varied growing conditions. The percentage ALA in the trail chips showed an increasing trend with the increasing inclusion rates. The levels of omega-3 in all trial chips were significantly greater than the control chip, which is the main advantage as this FA provides significant health benefits. With each inclusion rate $(5 \%, 10 \%, 12 \%$ and $15 \%)$ there was a significant increase in the ALA content. The results indicate that by even a $5 \%$ chia inclusion rate into a chip the health benefits of omega-3 FA could be achieved.

\subsection{Sensory Evaluation}

Sensory evaluation was conducted using the chia containing samples and a commercially available chip sample as the control. The selection of the commercial sample was explained earlier. The panellists were asked to assess appearance, colour, smell, texture, flavour and overall liking and rate the samples on a 9-point hedonic rating scale. From the sensory evaluation means plot (Figure 1), it can be seen that every aspect of the $5 \%$ chip was preferred, except for the texture, when compared to the three other trial chip samples. The commercial sample contained gums which could have contributed to the higher rating for texture. The experimental samples relied only on the chia gel to develop the texture.

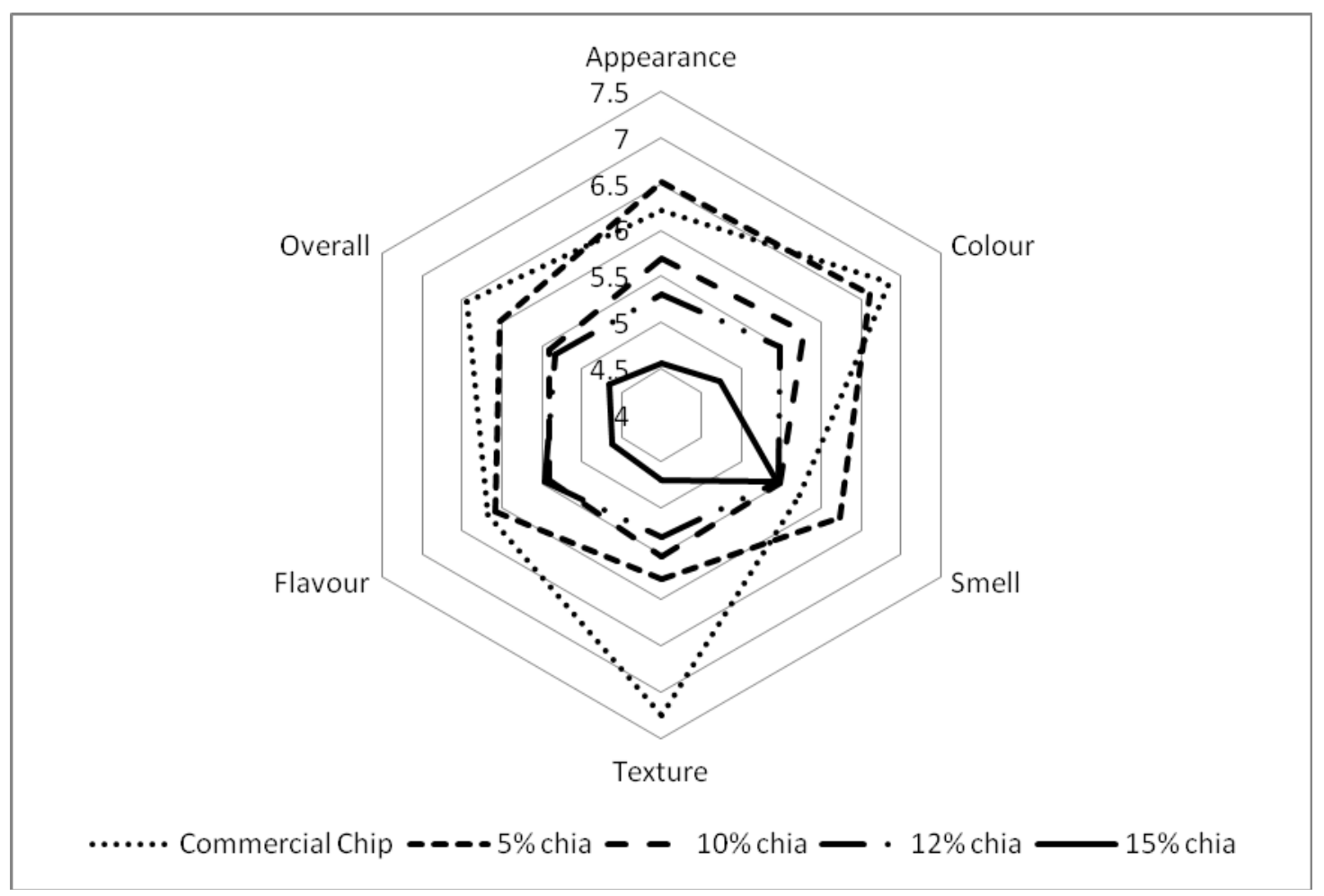

Figure 1. Results of sensory evaluation

In terms of appearance, the $5 \%$ chia sample was similar to the control and was liked significantly higher than any other trial chip sample $(\mathrm{P} \leq 0.05)$. The rating for appearance for $5 \%, 10 \%$, and $12 \%$ chia samples were not significantly different from the commercial brand chip sample (Table 4). The colour of the $5 \%$ chia sample was rated significantly higher than all other trial chip samples. The $5 \%$ and $10 \%$ chips were liked as much as the commercially available chip. The smell of the $5 \%$ chia sample was similar in smell to the control and significant higher than the other trial chips, which could mean the concentration of chia could have had an impact on the aroma of the chip. The commercial chip was liked significantly more than all the trial chips in terms of texture and there was no significant difference in preference for texture between the $5 \%$ and $10 \%$ chips and the $5 \%$ and $12 \%$ chips. In terms of flavour there was no difference in liking between the commercial chip and the $5 \%, 10 \%$ and $12 \%$ chips $(\mathrm{p}=>0.05)$. Overall the $5 \%$ chip was the only trial chip to be liked statistically as much as the commercial brand chip. 
Table 4. Sensory evaluation data

\begin{tabular}{llllllll}
\hline Sample & & Appearance & Colour & Smell & Texture & Flavour & $\begin{array}{l}\text { Overall } \\
\text { acceptability }\end{array}$ \\
\hline Control & (commercial chip) & $6.21^{\mathrm{ab}}$ & $6.86^{\mathrm{ab}}$ & $5.73^{\mathrm{ab}}$ & $7.25^{\mathrm{a}}$ & $6.17^{\mathrm{a}}$ & $6.44^{\mathrm{a}}$ \\
Treatment 1 & $(5 \%$ chia $)$ & $6.52^{\mathrm{b}}$ & $6.6^{\mathrm{a}}$ & $6.24^{\mathrm{a}}$ & $5.78^{\mathrm{b}}$ & $6.08^{\mathrm{a}}$ & $6.02^{\mathrm{ab}}$ \\
Treatment 2 & $(10 \%$ chia $)$ & $5.7^{\mathrm{a}}$ & $5.79^{\mathrm{bc}}$ & $5.49^{\mathrm{b}}$ & $5.54^{\mathrm{b}}$ & $5.4^{\mathrm{ab}}$ & $5.4^{\mathrm{b}}$ \\
Treatment 3 & $(12 \%$ chia $)$ & $5.3^{\mathrm{ac}}$ & $5.48^{\mathrm{cd}}$ & $5.46^{\mathrm{b}}$ & $5.33^{\mathrm{bc}}$ & $5.46^{\mathrm{ab}}$ & $5.32^{\mathrm{bc}}$ \\
Treatment 4 & $(15 \%$ chia $)$ & $4.56^{\mathrm{c}}$ & $4.73^{\mathrm{d}}$ & $5.44^{\mathrm{b}}$ & $4.71^{\mathrm{c}}$ & $4.62^{\mathrm{b}}$ & $4.65^{\mathrm{c}}$ \\
\hline
\end{tabular}

Different superscripts within a column denote significant differences $(\mathrm{P}<0.05)$.

\section{Conclusions}

As defined by the guidleins of the Australian New Zealand Food Authority (1995) proposed nutrient claims, chia incorporated chips can be used as an excellent sources of omega- $3 \mathrm{FA}$. A $50 \mathrm{~g}$ portion of the $5 \%$ chia chip, would provide almost half of the Recommended Daily Intake (RDI) of omega-3 FA for healthy women and just over a quarter for healthy men. The levels of dietary fibre, protein, calcium and antioxidants are also higher in $5 \%$ chia chip samples compared to the control. In terms of optimal consumer acceptance and nutritional benefit, the 5\% chip has the highest rating and is as acceptable as a commercially available product.

The $5 \%$ chia chip is liked just as much as the commercial brand chip in terms of appearance, colour, flavour and overall acceptability except for texture. This is a good indication that the $5 \%$ chia chip would be well accepted in the market place. Future research will need to establish the type of gum and its optimum level to be used in the manufacture of chia based chips. The high protein and fibre content enables excellent water holding capacity, making chia a useful ingredient for binding in gluten free products. The high antioxidant content is useful in shelf life extension, especially in foods high in unsaturated FA, such as omega-3. The use of chia in chips does not significantly change sensory acceptability. This research shows gluten free chip containing $5 \%$ chia, $3 \%$ dietary fibre, $6 \%$ anti-oxident activity $15 \mathrm{mg} / 100 \mathrm{~g}$ of omega- 3 and $40 \mathrm{mg} / 100 \mathrm{~g}$ calcium with good consumer acceptance can be developed. With limited healthy foods with good consumer acceptability currently available in the market, a chia chip would prove to be a novel, well accepted and healthy alternative to the unhealthy chips. Regular consumption of chia enriched chips could have a significant impact on health and well-being of consumers.

\section{Acknowledgements}

The Chia Company for the supply of chia.

\section{References}

[AOAC] Association of Official Analytical Chemists. (2005). Official methods of analysis (15th ed.). Virginia: Association of Official Analytical Chemist.

Adkins, Y., \& Kelley, D. S. (2010). Mechanisms underlying the cardioprotective effects of omega-3 polyunsaturated fatty acids. Journal of Nutritional Biochemistry, 21(9), 781-792. http://dx.doi.org/10.1016/j.jnutbio.2009.12.004

Alvarez-Chavez, L. M., Valdivia-Lopez, M. D., Aburto-Juarez, M. D., \& Tecante, A. (2008). Chemical characterization of the lipid fraction of Mexican chia seed (Salvia hispanica L.). International Journal of Food Properties, 11(3), 687-697. http://dx.doi.org/10.1080/10942910701622656

Australia New Zealand Food Authority. (1995). Code of Practice: Nutrient Claims in Food Labels and in Advertisements. Canberra: ANZFA. Retrieved from http://www.foodstandards.gov.au/ (April 8, 2011)

Ayerza, R. (1995). Oil content and fatty-acid composition of chia (Salvia-Hispanica) from 5 northwestern locations in Argentina. Journal of the American Oil Chemists Society, 72(9), 1079-1081. http://dx.doi.org/10.1007/BF02660727

Ayerza, R., \& Coates, W. (2005). Ground chia seed and chia oil effects on plasma lipids and fatty acids in the rat. Nutrition Research, 25(11), 995-1003. http://dx.doi.org/10.1016/j.nutres.2005.09.013

Bozan, B., \& Temelli, F. (2008). Chemical composition and oxidative stability of flax, safflower and poppy seed and seed oils. Bioresource Technology, 99(14), 6354-6359. http://dx.doi.org/10.1016/j.biortech.2007.12.009 
Brand-Williams, W., Cuvelier, M. E., \& Berset, C. (1995). Use of a Free-Radical Method to Evaluate Antioxidant

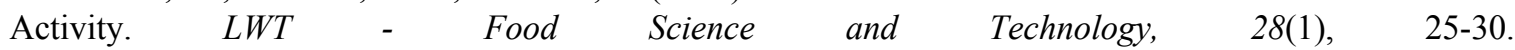
http://dx.doi.org/10.1016/S0023-6438(95)80008-5

Bushway, A. A., Belyea, P. R., \& Bushway, R. J. (1981). Chia seed as a source of oil, polysaccharide, and protein. Journal of Food Science, 46(5), 1349-1350. http://dx.doi.org/10.1111/j.1365-2621.1981.tb04171.x

Coates, W., \& Ayerza, R. (1998). Commercial production of chia in northwestern Argentina. Journal of the American Oil Chemists Society, 75(10), 1417-1420. http://dx.doi.org/10.1007/s11746-998-0192-7

Cummins, A. G., \& Roberts-Thomson, I. C. (2009). Prevalence of celiac disease in the Asia-Pacific region. Journal of Gastroenterology and Hepatology, 24(8), 1347-1351. http://dx.doi.org/10.1111/j.1440-1746.2009.05932.x

Dubois, V., Breton, S., Linder, M., Fanni, J., \& Parmentier, M. (2007). Fatty acid profiles of 80 vegetable oils with regard to their nutritional potential. European Journal of Lipid Science and Technology, 109(7), 710-732. http://dx.doi.org/10.1002/ejlt.200700040

Esposito, F., Arlotti, G., Bonifati, A. M., Napolitano, A., Vitale, D., \& Fogliano, V. (2005). Antioxidant activity and dietary fibre in durum wheat bran by-products. [Article]. Food Research International, 38(10), 1167-1173. http://dx.doi.org/10.1016/j.foodres.2005.05.002

Goren, A. C., Kilic, T., Dirmenci, T., \& Bilsel, G. (2006). Chemotaxonomic evaluation of Turkish species of Salvia: Fatty acid compositions of seed oils. Biochemical Systematics and Ecology, 34(2), 160-164. http://dx.doi.org/10.1016/j.bse.2005.09.002

Han, J., Janz, J. A. M., \& Gerlat, M. (2010). Development of gluten-free cracker snacks using pulse flours and fractions. Food Research International, 43(2), 627-633. http://dx.doi.org/10.1016/j.foodres.2009.07.015

Heuer, B., Yaniv, Z., \& Ravina, I. (2002). Effect of late salinization of chia (Salvia hispanica), stock (Matthiola tricuspidata) and evening primrose (Oenothera biennis) on their oil content and quality. Industrial Crops and Products, 15(2), 163-167. http://dx.doi.org/10.1016/S0926-6690(01)00107-8

Hui, Y. (2006). Handbook of Food Science, Technology, and Engineering Boca Raton: Taylor \& Francis Group.

Ixtaina, V. Y., Nolasco, S. M., \& Tomás, M. C. (2008). Physical properties of chia (Salvia hispanica L.) seeds. Industrial Crops and Products, 28(3), 286-293. http://dx.doi.org/10.1016/j.indcrop.2008.03.009

Luh, B. S. (1991). Rice Utilization (2nd ed. Vol. 2). New York Van Nostrand Reinhold

Mann, J., \& Truswell, S. (2007). Essentials of Human Nutrition (3 ed.). New York Oxford University Press.

Mishra, V. K., Temelli, F., \& Ooraikul, B. (1993). Extraction and purification of omega-3-fatty acids with an emphasis on supercritical-fluid extraction - a review. Food Research International, 26(3), 217-226. http://dx.doi.org/10.1016/0963-9969(93)90056-O

Mosse, J. (1990). Nitrogen to protein conversion factor for 10 cereals and 6 legumes or oil seeds - A reappraisal of its definition and determination - variation according to species and to seed protein - content Journal of Agricultural and Food Chemistry, 38(1), 18-24. http://dx.doi.org/10.1021/jf00091a004

Okuyama, H. (2001). High n-6 to n-3 ratio of dietary fatty acids rather than serum cholesterol as a major risk factor for coronary heart disease. European Journal of Lipid Science and Technology, 103(6), 418-422. http://dx.doi.org/10.1002/1438-9312(200106)103:6<418::AID-EJLT418>3.0.CO;2-\#

Olivos-Lugo, B. L., Valdivia-Lopez, M. A., \& Tecante, A. (2010). Thermal and Physicochemical Properties and Nutritional Value of the Protein Fraction of Mexican Chia Seed (Salvia hispanica L.). Food Science and Technology International, 16(1), 89-96. http://dx.doi.org/10.1177/1082013209353087

Phillips, K. M., TarragoTrani, M. T., Grove, T. M., Grun, I., Lugogo, R., Harris, R. F., \& Stewart, K. K. (1997). Simplified gravimetric determination of total fat in food composites after chloroform-methanol extraction. Journal of the American Oil Chemists Society, 74(2), 137-142. http://dx.doi.org/10.1007/s11746-997-0158-1

Quintero-Fuentes, X., McDonough, C. M., Rooney, L. W., \& Almeida-Dominguez, H. (1999). Functionality of rice and sorghum flours in baked tortilla and corn chips. Cereal Chemistry, 76(5), 705-710. http://dx.doi.org/10.1094/CCHEM.1999.76.5.705

Ramadan, M. F., \& Moersel, J. T. (2006). Screening of the antiradical action of vegetable oils. Journal of Food Composition and Analysis, 19(8), 838-842. http://dx.doi.org/10.1016/j.jfca.2006.02.013

Reyes-Caudillo, E., Tecante, A., \& Valdivia-Lopez, M. A. (2008). Dietary fibre content and antioxidant activity of 
phenolic compounds present in Mexican chia (Salvia hispanica L.) seeds. Food Chemistry, 107(2), 656-663. http://dx.doi.org/10.1016/j.foodchem.2007.08.062

Rubio-Rodriguez, N., Beltran, S., Jaime, I., de Diego, S. M., Sanz, M. T., \& Carballido, J. R. (2010). Production of omega-3 polyunsaturated fatty acid concentrates: A review. Innovative Food Science \& Emerging Technologies, 11(1), 1-12. http://dx.doi.org/10.1016/j.ifset.2009.10.006

Ruskey, F., \& Savage, C. (1993). Hamilton Cycles which Extend Transposition Matchings in Cayley Graphs of Sn. Journal on Discrete Mathematics, 6 (1), 152-166. http://dx.doi.org/10.1137/0406012

Sanchez-Moreno, C., Larrauri, J. A., \& Saura-Calixto, F. (1998). A procedure to measure the antiradical efficiency of polyphenols. Journal of the Science of Food and Agriculture, 76(2), 270-276. http://dx.doi.org/10.1002/(SICI)1097-0010(199802)76:2<270::AID-JSFA945>3.0.CO;2-9

SigmaAldrich. (1997). Technical documents: BCl3-Methanol 12\% w/w Retrieved 23 June, 2011, from http://sigmaaldrich.com

Standards Association of Australia. (1995). Australian Standards for Sensory Analysis: General guidelines to methodology - Selection of assessors. AS 2542.1.3-1995. Sydney: Standards Australia.

Standards Association of Australia. (2005). Australian Standards for Sensory Analysis: General guidelines to methodology - Types of tests. AS 2542.1.1-2005. Sydney: Standards Australia.

Standards Association of Australia. (2007). Australian Standards for Sensory Analysis: Specific methods Guidelines for the use of quantitative response scales (rating). AS 2542.2.3-2007. Sydney: Standards Australia.

Standards Association of Australia. (2007). Australian Standards for Sensory Analysis: Specific methods- Paired comparison test. AS 2542.2.1-2007. Sydney: Standards Australia.

Tepe, B., Sokmen, M., Akpulat, H. A., \& Sokmen, A. (2006). Screening of the antioxidant potentials of six Salvia species from Turkey. Food Chemistry, 95(2), 200-204. http://dx.doi.org/10.1016/j.foodchem.2004.12.031

The Chia Company. (2010). Vitamins, Minerals, Trace Elements \& Gluten. Retrieved from http://www.thechiaco.com.au/content/vitamins-minerals-trace-elements-gluten (April 8, 2010) 